\title{
Children in the London: Inpatient Care in a Voluntary General Hospital
}

\author{
MADELEINE MANT ${ }^{1,2} *$ \\ ${ }^{1}$ Memorial University of Newfoundland, Department of Archaeology Queen's College, \\ 210 Prince Philip Drive, St John's, NL A1B 3R6, Canada \\ ${ }^{2}$ Department of Anthropology, McMaster University, 1280 Main St. West, Hamilton,
} Ontario L8S 4L8, Canada

\begin{abstract}
The presence of children in English voluntary hospitals during the eighteenth century has only recently come under academic scrutiny. This research examines the surviving admission records of the London Hospital, which consistently record inpatient ages, to illuminate the hospital stays of infant and child patients and examine the morbidity of children during the long eighteenth century. Traumatic cases were the most common category of admission. The proportion of trauma cases admitted to the London Hospital was higher than in provincial English child patient cohorts, potentially reflecting the differential risks faced by rural and urban children. In most cases of traumatic injury the inpatients stayed in hospital long enough for significant fracture healing to have occurred. Understanding the conditions surrounding children's admission to hospital, their length of stay, the result of their stay, and which medical issues drove their parents or guardians to seek medical attention for them are critical to illuminating the morbidity of children during the long eighteenth century.
\end{abstract}

Keywords: Fracture, Children, Long eighteenth century, Hospital, London, Trauma

\section{Introduction}

Until recently, little attention has been paid to the treatment of child patients in eighteenth-century hospitals. Patient-focused studies have explored case records and others have investigated hospital admission records, but the primary focus has been on

* Email addresses for correspondence: mmant@mun.ca, maddymant@gmail.com Thank you to Jonathan Evans and Richard Meunier (Royal London Hospital Museum and Archives), Katie Ormerod (St Bartholomew's Hospital Archives and Museum), and Annie Lindsay (University College London Hospitals NHS Trust) for facilitating access to the hospital records. Thank you to Dr Megan Brickley and Dr Juanita DeBarros for their input on an earlier version of this research. Special thanks to Dr Ann Herring for her constructive insights concerning an early draft of this manuscript and to Dr Rachel Ives for her assistance in tracking down primary sources regarding London's demographic structure. Thank you also to the two anonymous reviewers, whose suggestions greatly improved this paper. 
adult inpatients. ${ }^{1}$ More recent work concerning children in eighteenth-century English provincial hospitals clearly demonstrates the presence of children in these charitable institutions. ${ }^{2}$ These works articulate the common themes found in medical history and childhood studies, and how these fields, when examined together, can help demystify the interactions of poor child patients with the medical institutions of the eighteenth century.

Poverty was not static or absolute during the long eighteenth century and poor individuals might require varied forms of formal and informal social welfare during the course of their lives. In fact, individuals were likely to change financial status throughout their lives. ${ }^{3}$ This life-cycle poverty has been addressed in the rich historiography of the poor law, revealing key points in individuals' lives when the risk of financial crisis was highest, namely childhood, young parenthood, and old age. ${ }^{4}$ Sickness or an accident could '[propel] people into poverty' due to the combined effects of reducing their ability to work and requiring the immediate outlay of resources. ${ }^{5}$ When faced with sickness, the poor had a variety of options available, including paying out of pocket for a practitioner's expertise, consulting kin and neighbours, calling upon the membership of a Friendly Society for aid, applying to the parish for poor relief, or seeking admittance to a voluntary infirmary. ${ }^{6}$ The question, according to Mary Fissell, is 'why and how certain groups came to rely upon institutions to provide health care', considering the variety of resources available. 7

\footnotetext{
${ }^{1}$ For hospital case records, see Jonathan Reinarz, 'Unearthing and Dissecting the Records of English Provincial Medical Education, c.1825-1948', Social History of Medicine, 21 (2008), 381-92; Ortrun Riha, 'Surgical Case Records as an Historical Source: Limits and Perspectives', Social History of Medicine, 8 (1995), 271-83; Guenter B. Risse and John H. Warner, 'Reconstructing Clinical Activities: Patient Records in Medical History', Social History of Medicine, 5 (1992), 183-205. For admission records, see Mary E. Fissell, Patients, Power, and the Poor in Eighteenth-Century Bristol (Cambridge: Cambridge University Press, 1991); Jonathan Reinarz, The Birth of a Provincial Hospital: The Early Years of the General Hospital, Birmingham, 1765-1900 (Stratfordupon-Avon: Shakespeare Birthplace Trust, 2003); Guenter B. Risse, Hospital Life in Enlightenment Scotland: Care and Teaching at the Royal Infirmary of Edinburgh (Cambridge: Cambridge University Press, 1986); Kevin P. Siena, Venereal Disease, Hospitals and the Urban Poor: London's 'Foul Wards', 1600-1800 (New York: Rochester, 2004).

${ }^{2}$ Alysa Levene, Jonathan Reinarz and Andrew Williams, 'Child Patients, Hospitals and the Home in EighteenthCentury England', Family \& Community History, 15 (2012), 15-33; Andrew N. Williams and Raman M. Sharma, 'Children in Hospitals Before There Were Children's Hospitals', Pediatrics, 134 (2014), 425-7; Andrew N. Williams, 'Eighteenth-Century Child Health Care in a Northampton Infirmary: A Provincial English Hospital', Family \& Community History, 10 (2007), 153-66. Though they are not the primary focus, children do appear in the admission records examined by Fissell, op. cit. (note 1), 103, for Bristol, and see Margaret Pelling, The Common Lot: Sickness, Medical Occupations and the Urban Poor in Early Modern England (London and New York: Longman, 1998), for Norwich.

${ }^{3}$ Alysa Levene, general introduction in S. King, T. Nutt, and A. Tomkins (eds), Narratives of the Poor in Eighteenth-Century Britain, Vol. 1 (London: Pickering \& Chatto, 2006), vii-xix: ix; Mary Fissell, 'The "Sick and Drooping Poor" in Eighteenth-Century Bristol and its Region', Social History of Medicine (1989), 35-58: 36.

${ }^{4}$ Samantha Williams, Poverty, Gender and Life-Cycle under the English Poor Law, 1760-1834 (Woodbridge: Boydell \& Brewer, 2011), 12-3. Further explorations of intermittent uses of poor law relief are explored in Tim Wales, 'Poverty, poor relief and life-cycle: some evidence from seventeenth-century Norfolk', in R.M. Smith (ed.), Land, Kinship and Life-Cycle (Cambridge: Cambridge University Press, 1984), 351-404: 358; Barry Stapleton, 'Inherited Poverty and Life-Cycle Poverty: Odiham, Hampshire 1650-1850', Social History, 18 (1993), 339-55; Steven King, Poverty and Welfare in England 1700-1850: A Regional Perspective (Manchester: Manchester University Press, 2000), 132.

5 Alannah Tomkins, The Experience of Urban Poverty, 1723-82: Parish, Charity and Credit (Manchester: Manchester University Press, 2006), 120.

${ }^{6}$ For a discussion of Friendly Societies and their relationship to medical care provision, see Joan Lane, A Social History of Medicine: Health, Healing and Disease in England, 1750-1950 (London and New York : Routledge, 2001), 73-8.

${ }^{7}$ Fissell, op. cit. (note 3), 38.
} 
Indeed, the voluntary hospitals did not operate in isolation; they stood against a complex backdrop of potential sources of medical advice and care. Parish relief under the Old Poor Law, spending on which grew steadily between 1696 and 1803, was 'neither ineffective nor ungenerous ${ }^{8}$ and could provide money for births, medical practitioners' services and burials. ${ }^{9}$

Studies of poverty have been criticised for being 'rarely concerned with the poor as subjects of their own stories' ${ }^{10}$ and there is an increasing desire to bring attention to 'the experiences of, responses to, and realities of their lives as individuals' ${ }^{11}$ through a history-from-below approach. Institutional records for a delimited population, such as the hospital admittance records under scrutiny, capture individuals who represent a specific subgroup of London's populace. Poor children's dealings with the medical marketplace have previously been obscured since they were generally not the ones making primary decisions concerning their medical care and their reactions to their health care were not often recorded. This article is among the first to quantitatively investigate the hospital admission of children of the working poor in London, contributing insight into their interaction with the medical marketplace through a study of children admitted to the London Hospital.

This research probes a series of admission records from the London Hospital, a voluntary hospital in London, UK founded in 1740. These records provide a dataset with which to compare the child inpatient results described by Levene and colleagues, drawn from eighteenth-century English towns. ${ }^{12}$ This article seeks to explore the following questions. First, for what medical or surgical conditions were children most commonly being admitted to the London Hospital? Second, on average how long were child inpatients spending in hospital? Third, what was the result of their inpatient stay? The admission records affirm the contemporary reputation of the London Hospital as a destination for trauma cases and illustrate the myriad risks to children's health in eighteenth-century London, particularly the effects of traumatic injury.

\section{General Hospitals in London}

The eighteenth century saw the rise of the general hospital movement in England; this period has been nicknamed the Age of Hospitals. ${ }^{13}$ London boasted seven general institutions, which provided approximately two thousand beds for the poor. ${ }^{14}$ Four of these hospitals, the Westminster, St George's, the London and the Middlesex, depended upon public donations and subscriptions to provide charitable care. The others, St Bartholomew's, St Thomas's and Guy's, were independently endowed and could therefore survive without appealing to the public for donations. ${ }^{15}$ These institutions were designed

\footnotetext{
${ }^{8}$ John Rule, 'The labouring poor', in H.T. Dickenson (ed.), A Companion to Eighteenth-Century Britain (Oxford: Blackwell, 2002), 183-95: 184.

${ }^{9}$ Paul Slack, The English Poor Law 1531-1782 (London: MacMillan, 1990), 30-1.

${ }^{10}$ Roxanne Rimstead, Remnants of Nation: On Poverty Narratives by Women (Toronto: University of Toronto Press, 2001), 23.

${ }^{11}$ Levene, op. cit. (note 3), xix.

12 Levene et al. op. cit. (note 2), 19.

13 Courtney Dainton, The Story of England's Hospitals (Springfield, IL: Thomas, 1961).

${ }^{14}$ Joan Lane, A Social History of Medicine: Health, Healing and Disease in England, 1750-1950 (London and New York: Routledge, 2001).

${ }^{15}$ See histories of the general hospital movement, for example Geoffrey Rivett, The Development of the London Hospital System, 1823-1982 (London: King Edward's Hospital Fund for London, 1986); John Woodward,
} 
to treat the working poor, wage-labouring individuals who could not afford to pay for private medical care; they were expected to return to work following treatment.

Admittance criteria to these seven institutions were strict, and dictated that only individuals deemed 'deserving' or 'worthy objects of charity' could be treated. ${ }^{16}$ In essence, the hospitals sought to treat those who could otherwise work in order to '[recover] future wealth potentially lost to the nation'. ${ }^{17}$ Individuals seeking hospital admittance could only gain access if they were recommended by a hospital governor or subscriber (an individual who donated money to the hospital in exchange for the right to recommend annually a certain number of patients for treatment), unless they had suffered an accident. ${ }^{18}$ Hospitals focused on the care of curable injuries and illnesses, discouraging the admittance of chronic cases or those deemed incurable; these would take up beds that could otherwise be used by patients suffering from acute maladies. The London Hospital, in its 1762 instructions to those recommending patients for admittance, explained clearly that

\begin{abstract}
'no woman big with child, no children under seven years of age (except in cases of compound fractures, amputations, or cutting for the stone [i.e., lithotomy procedure to remove bladder stones]) no persons disordered in their senses, or suspected to have Smallpox, Itch, or other infectious distempers, or who are judged to be in a consumptive, asthmatic, or dying condition'
\end{abstract}

were to be admitted. ${ }^{19}$ The exclusion of children is critical, because juvenile individuals were certainly being accepted at English voluntary hospitals, all of which had similar strict admittance policies. ${ }^{20}$

Specialist medical care for children in London was limited. The London Foundling Hospital, an orphanage, was established in 1739 and a dispensary for the infant poor was founded in 1769, but until the founding of the Great Ormond Street Hospital for Children in 1852, there were no institutions that specifically catered for children's inpatient medical care. ${ }^{21}$ Workhouses sometimes accepted pauper children with medical issues, including the infectious and chronic conditions frowned upon by voluntary hospitals, such as smallpox and fever diseases. ${ }^{22}$

Children in London's voluntary general hospitals have received insufficient attention by researchers, due to the fact that age was almost never recorded for inpatients. Intermittent admission and discharge records have survived for St Thomas's Hospital with some admitted individuals labelled as 'child' or 'infant'; from 1773 to 1796 children make up less than five per cent of all admissions and reasons for admission were rarely recorded. ${ }^{23}$ Apothecary reports from the Middlesex Hospital (1760-4, 1771-8) record scattered cases

To Do the Sick No Harm: A Study of the British Voluntary Hospital System to 1875 (London: Routledge \& Kegan Paul, 1974); G.B. Carruthers and Lesley A. Carruthers, A History of Britain's Hospitals and the Background to the Medical, Nursing and Allied Professions (Lewes: Book Guild Publishing, 2005); Susan Lawrence, Charitable Knowledge: Hospital Pupils and Practitioners in Eighteenth-Century London (Cambridge: Cambridge University Press, 1996).

16 Woodward, op. cit. (note 15), 40.

${ }^{17}$ Lawrence, op. cit. (note 15), 45.

${ }^{18}$ Harold W. Hart, 'Some Notes on the Sponsoring of Patients for Hospital Treatment under the Voluntary System', Medical History, 24 (1980), 447-60.

19 Quoted in Ibid., 448.

${ }^{20}$ Levene et al., op. cit. (note 2), 17; Williams, op. cit. (note 2), 158.

${ }^{21}$ Ruth McClure, Coram's Children: The London Foundling Hospital in the Eighteenth Century (New Haven, CT: Yale University Press, 1981); Peter Dunn, 'George Armstrong MD (1719-1789) and his Dispensary for the Infant Poor', Archives of Disease in Childhood: Fetal and Neonatal Edition, 87 (2002), F228-31.

${ }^{22}$ Alysa Levene, The Childhood of the Poor: Welfare in Eighteenth-Century London (London: Palgrave Macmillan, 2012), 120.

${ }^{23}$ Ibid., 147. 
of child inpatients admitted for fractures, burns, and scalds. ${ }^{24}$ Further, there is evidence that some child patients received outpatient care and clinical consultation at St Bartholomew's Hospital. ${ }^{25}$ Inconsistently recorded reasons for admission limit the comparability of these records to those from the London Hospital, but they emphasise that children were on occasion being accepted at London's voluntary general hospitals.

\section{Child Patients at the London Hospital}

The London Hospital, founded in 1740, was built facing Whitechapel Road, in east London. The hospital received its Royal designation in 1990 on its 250th anniversary. The hospital's house committee admitted patients (excluding acute cases who could be admitted at any time) who arrived at the hospital with a governor's letter of recommendation. ${ }^{26}$ The London did not charge a burial deposit or 'caution money', a deposit paid upon admittance to cover the costs in the case of a patient's death, probably making it a particularly attractive institution at which to seek medical care. ${ }^{27}$

This research examined the surviving admission and discharge registers of the London Hospital. Registers from 1760, 1791, 1792, and the latter half of 1805 are extant and available for consultation. ${ }^{28}$ The records for 1805 did not record the ages of the inpatients and were thus excluded. The London Hospital records provide information on the patient's name, parish of abode, occupation, age, reason for admission, result of hospital stay and date of discharge. The three full years available allow for comparison within this institution. No case descriptions are available for the London Hospital, but casebooks from St George's Hospital and death records from St Bartholomew's Hospital covering the early nineteenth century were consulted and are used to illustrate some roughly contemporary experiences of children admitted to the London Hospital.

The total number of patients admitted to the London Hospital in the three years under investigation was divided into two groups: children thirteen and under, and those seven and under, following the framework used by Levene and colleagues in their study of provincial voluntary hospitals to allow for inter-hospital comparisons. ${ }^{29}$ The average age of apprenticeship in children of the working poor was thirteen and this age is thus chosen as the terminus of childhood, though it is acknowledged that the differentiation between children and adults is a social categorisation that has changed through time. ${ }^{30}$ The age of seven is important since the London Hospital specifically prohibited the admittance of children under this age. ${ }^{31}$

\footnotetext{
${ }^{24}$ Middlesex Hospital Apothecary Reports, University College London Hospitals NHS Trust, Vols 1-4.

${ }^{25}$ Levene, op. cit. (note 22), 121-2.

${ }^{26}$ Louise Fowler and Natasha Powers, 'Patients, anatomists and resurrection men: archaeological evidence for anatomy teaching at the London Hospital in the early nineteenth century', in P. Mitchell (ed.), Anatomical Dissection in Enlightenment England and Beyond (Farnham: Ashgate, 2012), 77-94: 78-9.

${ }^{27}$ Hart, op. cit. (note 18), 452.

${ }^{28}$ Royal London Hospital Archives and Museum LH/M/1/1 1760; Royal London Hospital Archives and Museum LH/M/1/2 1791-1792.

${ }^{29}$ Levene et al., op. cit. (note 2), 18.

${ }^{30}$ For apprenticeship age, see Katrina Honeyman, Child Worker in England, 1780-1820: Parish Apprenticeship and the Making of the English Industrial Labour Force (Aldershot: Ashgate, 2007). For age as social categorisation, see Allison James and Alan Prout, introduction in A. James and A. Prout (eds), Constructing and Reconstructing Childhood: Contemporary Issues in the Sociological Study of Childhood (Basingstoke: Macmillan, 1990), 1-5; Levene, op. cit. (note 22), 16; Hannah Newton, 'The Sick Child in Early Modern England, 1580-1720', Endeavour, 38 (2014), 122-29: 122.

${ }^{31}$ Exceptions to this prohibition are listed above (see note 19).
} 


$\begin{array}{lcccc}\text { Year } & 1760 & 1791 & 1792 & \text { Average } \\ \text { Annual total of patients admitted } & 1425 & 1075 & 1077 & 1192 \\ \text { N children thirteen or under } & 75 & 40 & 46 & 53.7 \\ \% \text { children thirteen } \text { or under } & 5.3 & 3.7 & 4.3 & 4.4 \\ \text { N children seven } \text { or under } & 16 & 11 & 11 & 12.7 \\ \% \text { children seven } \text { or under } & 1.1 & 1.0 & 1.0 & 1.0\end{array}$

Table 1: Number of child patients admitted to the London Hospital, 1760, 1791 and 1792.

Table 1 displays the total number of individuals, adults and children, admitted to the London Hospital in each year. Overall, the proportion of inpatients under the age of thirteen was low, ranging from 3.7 to 5.3 per cent; those under the age of seven constituted between 1.0 and 1.1 per cent of the inpatient population. These results are uniformly lower than those described by Levene and colleagues, despite the fact that the average inpatient cohort in this investigation was higher at 1192, compared with $928 .^{32}$ Anne Borsay's study of the admission records from the infirmary at Bath between 1742 and 1752, where inpatient ages were recorded, also demonstrated a higher percentage of admitted children, with 8.72 per cent of all inpatients falling between the ages of 0 and 14. ${ }^{33}$ The London Hospital results potentially reflect a stricter adherence to the hospital admittance guidelines in addition to the wide variety of medical options available to the parents of ill children in London: other voluntary general hospitals, dispensaries and alternative medical practitioners. Borsay and Mary Fissell, in her study of the Bristol Infirmary, compare the inpatient age groups with age structure data for England as whole, from Wrigley and Schofield's population reconstruction of England. ${ }^{34}$ They note that children are underrepresented in both the Bath and Bristol Infirmaries, a result also found at the London Hospital. Although there are inherent limitations present when attempting to apply broad population data as a comparative source to a geographically limited sample, it is interesting to note that between 1756 and 1796 (years chosen to encompass the available London Hospital admission records) an estimated 33.1-36.8 per cent of the residents of England were between the ages of 0 and 14 while only an average of 4.4 per cent of child inpatients at the London Hospital were between the ages of 0 and 13. ${ }^{35}$ The Medical Register, compiled in 1783, indicates that in London alone there were 968 registered surgeons, apothecaries and physicians, though this total does not include the many alternative and fringe medicinal practitioners such as quacks, bone-setters and wise women. ${ }^{36}$ In 1783 the English provinces had the ratio of one medical practitioner to

\footnotetext{
32 Levene et al., op. cit. (note 2), 19.

33 Anne Borsay, Medicine and Charity in Georgian Bath: A Social History of the General Infirmary c.1739-1830 (Aldershot: Ashgate, 1999), 226.

${ }^{34}$ Ibid., 226; Fissell, op. cit. (note 1), 103.

35 E.A. Wrigley and R. Schofield, The Population History of England, 1541-1871 (Cambridge, MA: Harvard University Press, 1981), 529. Following the example of Mary Fissell (op. cit. (note 3), 46) I used the lowest and highest values for the period from 1756 to 1796 (encompassing the dates of the available admission books) for the age groups 0-4 and 5-14 years of age.

${ }^{36}$ W.F. Bynum, 'Physicians, hospitals, and career structures in eighteenth-century London', in W.F. Bynum and R. Porter (eds), William Hunter and the Eighteenth-Century Medical World (Cambridge: Cambridge University Press, 1985), 105-28: 107; Roy Porter, Health for Sale: Quackery in England 1660-1850 (Manchester: Manchester University Press, 1989), 60-90.
} 


$\begin{array}{lcccc} & \begin{array}{c}1760 \\ (\%)\end{array} & \begin{array}{c}1791 \\ (\%)\end{array} & \begin{array}{c}1792 \\ (\%)\end{array} & \begin{array}{c}\text { Inpatient } \\ \text { Stay* (n) }\end{array} \\ \text { Category of admission } & & & & \\ \text { Circulatory disorders } & 4.0 & 0.0 & 0.0 & 50.0(1) \\ \text { Diseases of the digestive system } & 5.3 & 0.0 & 0.0 & 33.3(4) \\ \text { Diseases of the skin } & 4.0 & 5.0 & 4.3 & 67.7(6) \\ \text { Eye problems } & 1.3 & 0.0 & 0.0 & 92.0(1) \\ \text { Genito-urinary } & 6.7 & 7.5 & 4.3 & 55.0(6) \\ \text { Infectious diseases } & 8.0 & 2.5 & 2.1 & 23.2(6) \\ \text { Miscellaneous medical } & 1.3 & 2.5 & 0.0 & 64.0(1) \\ \text { Miscellaneous surgical } & 0.0 & 0.0 & 2.1 & 54.0(1) \\ \text { Musculoskeletal disorders } & 6.7 & 7.5 & 17.0 & 42.4(15) \\ \text { Neurological and mental diseases } & 8.0 & 0.0 & 8.5 & 31.5(8) \\ \text { Respiratory diseases } & 1.3 & 0.0 & 0.0 & 22.0(1) \\ \text { Surgical infections } & 12.0 & 10.0 & 2.1 & 59.8(10) \\ \text { Surgical procedures } & 0.0 & 0.0 & 4.3 & 66.0(1) \\ \text { Traumatic conditions } & 37.3 & 52.5 & 45.7 & 34.4(59) \\ \text { Tumours and cancers } & 0.0 & 0.0 & 2.1 & 92.0(1) \\ \text { Unknown } & 4.0 & 12.5 & 6.4 & 53.2(10) \\ \text { N } & 75 & 40 & 46 & \end{array}$

* Inpatient stay is the average number of days spent in hospital by those children who were eventually discharged as 'cured' or 'relieved' (recorded as n). Those who died, returned, or were removed from hospital before official discharge were not included in the average.

Table 2: Classification of diseases among child patients admitted to the London Hospital, 1760, 1791 and 1792.

2224 people; London's ratio was about three times better. ${ }^{37}$ Outpatient care was provided by the dispensaries on a charitable basis; by 1800 there were twenty-one dispensaries in London alone, with a further twenty-two located in the rest of Britain. ${ }^{38}$ Beyond hospitals, dispensaries and alternative practitioners, the independence of ill individuals was heightened by the publication of self-help tomes such as John Wesley's Primitive Physick, which championed natural holism and cold water therapy, and William Buchan's Domestic Medicine, which proposed a philosophy of health based upon hygiene and temperance and included descriptions of specific care for children. ${ }^{39}$ These volumes, published in English rather than Latin to appeal to a literate lay medical audience, went through many editions, indicating the popularity of self-help. There was clearly a range of choice in London's medical marketplace outside individuals' family and community networks, in which the voluntary hospitals were only one option, if parents sought to seek health care for their children outside the home.

Table 2 summarises the reasons for children's admission and the average inpatient stay at the London Hospital following the categories set out by Risse's study of the admission records of the Royal Infirmary of Edinburgh, subsequently used by Levene

\footnotetext{
37 Anne Digby, Making a Medical Living: Doctors and Patients in the English Market for Medicine, 1720-1911 (Cambridge: Cambridge University Press, 1994), 20.

${ }^{38}$ Bronwyn Croxon, 'The Public and Private Faces of Eighteenth-Century London Dispensary Charity', Medical History, 41 (1997), 127-49; Irvine Loudon, 'The Origins and Growth of the Dispensary Movement in England', Bulletin of the History of Medicine, 16 (1981), 322-42.

39 John Wesley, Primitive Physick, or, An Easy and Natural Method of Curing Most Diseases (London, 1747; Santa Barbara, CA: Woodbridge, 1975); William Buchan, Domestic Medicine, or, A Treatise on the Prevention and Cure of Diseases by Regiment and Simple Medicines (Edinburgh: Balfour, Auld \& Smellie, 1769).
} 
Category of admission

Circulatory disorders

Diseases of the digestive system

Diseases of the skin

Eye problems

Genito-urinary

Infectious diseases

Miscellaneous medical

Miscellaneous surgical

Musculoskeletal disorders

Neurological and mental diseases

Respiratory diseases

Surgical infections

Surgical procedures

Traumatic conditions

Tumours and cancers

Unknown

$\mathrm{N}$

\begin{tabular}{rr} 
Cured/relieved \\
$\mathrm{n}$ & \multicolumn{1}{c}{$\%$} \\
& \\
1 & 33.3 \\
4 & 100.0 \\
6 & 85.7 \\
1 & 100.0 \\
6 & 60.0 \\
6 & 75.0 \\
1 & 50.0 \\
1 & 100.0 \\
15 & 93.8 \\
8 & 80.0 \\
1 & 100.0 \\
10 & 71.4 \\
1 & 50.0 \\
58 & 82.9 \\
1 & 100.0 \\
10 & 90.9 \\
130 & 80.7
\end{tabular}

$\mathrm{n}$

$\% \quad \mathrm{n} \quad \%$

Total

33.3
0
0
0
30.0
12.5
0
0
0
0
0
0
50.0
11.4
0
9.1
9.3

$\begin{array}{cr}33.3 & 3 \\ 0 & 4 \\ 14.3 & 7 \\ 0 & 1 \\ 10.0 & 10 \\ 12.5 & 8 \\ 50.0 & 2 \\ 0 & 1 \\ 6.3 & 16 \\ 20.0 & 10 \\ 0 & 1 \\ 28.6 & 14 \\ 0 & 2 \\ 5.7 & 70 \\ 0 & 1 \\ 0 & 11 \\ 9.9 & 161\end{array}$

* Results in the 'Other' category included children who were removed from the hospital early, those labelled 'went away with leave', those who 'won't stay' and those whose fate was labelled as 'unknown'.

Table 3: Result of inpatient stay.

and colleagues; the results of these inpatient stays are recorded in Table $3 .{ }^{40}$ Traumatic conditions were the most common reason for admission each year and further detail is provided concerning this category in Table 4. Boys were consistently admitted more frequently than girls; boy inpatients made up an average of 63.4 per cent of the annual admissions for children. Levene and colleagues similarly noted that boys were more commonly admitted as surgical patients than girls, citing that potentially 'boys and girls experienced different risks of injury and accident in their daily work and play; that they were treated differently by hospital authorities; or that parents distinguished between sons and daughters when seeking medical assistance'. ${ }^{41}$ Previous studies have found more adult male than female inpatients, demonstrating the valuing of male labour and occupational hazards facing males during the long eighteenth century. ${ }^{42}$ Further, removing women from their households was discouraged as a potential cause of familial instability, with eighteenth-century dispensary founders warning that their hospitalisation could lead to 'dangerous consequences'. ${ }^{43}$

\footnotetext{
${ }^{40}$ Risse, op. cit. (note 1), 124; Levene et al., op. cit. (note 2), 22.

${ }^{41}$ Levene et al., op. cit. (note 2), 20.

42 Risse, op. cit. (note 1), 158; Siena, op. cit. (note 1), 165; Amanda Berry, 'Community sponsorship and the hospital patient in late eighteenth-century England', in P. Horden and R. Smith (eds), The Locus of Care: Families, Communities, Institutions and the Provision of Welfare since Antiquity (London and New York: Routledge, 1998), 126-50: 139; Madeleine Mant, 'Slips, Trips, Falls, and Brawls: Fractures of the Working Poor in London during the Long Eighteenth Century' (unpublished PhD thesis: McMaster University, 2016), 103,198

43 Donna Andrew, 'Two medical charities in eighteenth-century London', in J. Barry and C. Jones (eds), Medicine and Charity Before the Welfare State (London and New York: Routledge, 1991), 88; quotation from Bronwyn Croxson, 'The Public and Private Faces of Eighteenth-Century London Dispensary Charity', Medical History, 41 (1997), 127-49: 137.
} 


\begin{tabular}{|c|c|c|c|c|c|c|}
\hline \multirow[b]{2}{*}{ Traumatic condition category } & \multicolumn{2}{|c|}{1760} & \multicolumn{2}{|c|}{1791} & \multicolumn{2}{|c|}{1792} \\
\hline & $\mathrm{n}$ & $\% *$ & $\mathrm{n}$ & $\%$ & $\mathrm{n}$ & $\%$ \\
\hline Bruise/jammed/contusion & 6 & 21.4 & 1 & 4.8 & 0 & 0 \\
\hline Scald & 1 & 3.6 & 1 & 4.8 & 1 & 4.8 \\
\hline Wound & 6 & 21.4 & 6 & 28.6 & 6 & 28.6 \\
\hline Burn & 2 & 7.1 & 2 & 9.5 & 3 & 14.3 \\
\hline Dislocation & 2 & 7.1 & 0 & 0 & 0 & 0 \\
\hline Sprain & 1 & 3.6 & 0 & 0 & 0 & 0 \\
\hline Fracture & 10 & 35.7 & 11 & 52.4 & 11 & 52.4 \\
\hline $\mathrm{N}$ & 28 & & 21 & & 21 & \\
\hline
\end{tabular}

* Percentages may not total exactly $100 \%$ due to rounding.

Table 4: Details of traumatic condition category.

The treatment of children, especially those explicitly prohibited, suggests that they were valued for their future labour potential. ${ }^{44}$ This mercantilist view, that medical care for children through a paternalist hospital was an investment in future labour, is echoed in John Bellers' 1714 treatise, stating that the early death of an adult labourer 'may be accounted two hundred pounds loss to the kingdom'. ${ }^{45}$ Children between the age of five, when they 'achieved a degree of physical independence', and apprenticeship were of particular concern; if they were to become disabled or otherwise unable to work during this time they were unlikely to achieve an apprenticeship and become viable workers. ${ }^{46}$ It was therefore in the best interests of the hospitals, and by extension the nation, to accept children who arrived with conditions deemed treatable. This is not to suggest that parents did not feel concern and love for their children, a point that has been well established in the literature. ${ }^{47}$ A sick child represented both a source of stress and a risk to his or her family's financial situation. Wider social provisions for children in the form of parish poor relief - such as pensions, clothing, shoes and tools - and apprenticeships clearly 'illustrate the perceived social value of the health of children'. ${ }^{48}$ Emotional and economic investments were therefore both key factors in seeking medical care for a child. The goals of the hospital echoed those of the Old Poor Law - to ensure that the able-bodied were restored to their ability to work. Sickness and injury have been identified by scholars of the Old Poor Law as major drivers in the determination of poor relief. ${ }^{49}$ Both the overseers of the Poor Law and the voluntary hospitals recognised that upfront costs for medical treatment

\footnotetext{
44 Levene, op. cit. (note 22), 5, 121; Margaret Pelling, 'Child Health as a Social Value in Early Modern England', Social History of Medicine, 1 (1988), 135-64: 141; Borsay, op. cit. (note 33), 211-13: 218.

45 John Bellers, 'Essay Towards the Improvement of Physic', in G. Clarke (ed.), John Bellers: His Life, Times and Writings (London: Routledge and Kegan Paul, 1987), 178-9.

${ }^{46}$ Margaret Pelling, 'Apprenticeship, Health and Social Cohesion in Early Modern London', History Workshop, 37 (1994), 33-56: 34.

47 Pelling, op. cit. (note 2), 108; Diana Gittins, 'The historical construction of childhood', in M.H. Kehily (ed.), An Introduction to Childhood Studies, 2nd edn (Maidenhead: McGraw Hill for Open University Press, 2008), 35-49, 43; Linda A. Pollock, Forgotten Children: Parent-Child Relations from 1500-1900 (Cambridge: Cambridge University Press, 1983), 17.

48 Pelling, op. cit. (note 2), 107. See more on children's relationship with poor relief in Williams, op. cit. (note 4), $15-16,104$

${ }^{49}$ Fissell, op. cit. (note 1), 106; Hilary Marland, Medicine and Society in Wakefield and Huddersfield 1780-1870 (Cambridge: Cambridge University Press, 1987), 172, 196; E.G. Thomas, 'The Old Poor Law and Medicine', Medical History, 24 (1980), 1-19: 6.
} 
represented long term investments in individuals who would, if restored to health, be less likely to require chronic care. ${ }^{50}$

The vast majority of the child patients accepted at the London Hospital were registered as inhabitants of the eastern districts of London, such as Whitechapel, St George in the East, Spitalfields, Shoreditch, and Bethnal Green. This suggests that proximity to the hospital was a major factor in deciding to seek admission to the London Hospital. There are some interesting exceptions, however, where children were brought to the hospital from areas further afield. John Phipps, a thirteen-year-old boy from Datchworth, north of London, was admitted to the London with a diseased nose, and stayed as an inpatient for 113 days before being discharged as cured. Two children were admitted a day apart, 20 December and 21 December 1791, for the stone. This was an admittance allowed by the hospital's policies, but it is interesting to note that these children, a labourer's child and a farmer's son, resided in Purleigh, Essex, located nearly forty miles north-east of the hospital. Clearly the desire for surgical intervention motivated the parents to bring the children to hospital, suggesting that the hospital may have been perceived as more trustworthy or professional than locally available practitioners. The boys' ultimate fates differed drastically; one was cured and discharged fifty days after admittance, the other died eleven days following his admission. There is no information recorded as to whether or not the boys were ultimately cut for the stone, leaving tantalising, but unanswered questions about the medical care experienced by these children.

The range of illnesses and conditions affecting child inpatients was vast. Several admission classifications had low intake in all three years under study: the circulatory disorder group (comprising mostly dropsy cases), digestive system disorders (those with bloody flux - diarrhoeal disease - and worms), skin diseases (mainly scurvy and skin eruptions), eye problems, respiratory diseases, tumours and cancers, and miscellaneous categories. The majority of children in the genito-urinary category were admitted for the stone; musculoskeletal disorders included diseased and inflamed joints; and the majority of the surgical infections category comprised abscesses. Surgical procedures included two cases of amputation, one of which was successful and resulted in John Douglass, an eight-year-old boy from St George in the East, being discharged as cured after a stay of sixty-six days. The other case resulted in the death of seven-year-old William Messer, also of St George, after a stay of 102 days. Overall, categories with the highest intake mostly represent conditions that could be treated with medical or surgical interventions, similar to the results described by Levene and peers. ${ }^{51}$ Interestingly, children were admitted with infectious disease (eight cases diagnosed as 'fever' or 'ague'), though the average proportion of total cases (4.2\%) is lower than in five of the six cohorts studied by Levene and colleagues. ${ }^{52}$ The neurological category is, on average (5.5\%), higher than in five of the six provincial cohorts, and this diagnosis included one case of palsy, two of paralysis, and four of epilepsy, one concussion, and two cases of St Vitus's Dance. These results demonstrate that despite the clear guidelines for admissions there were still young patients being admitted with either infectious or chronic conditions. These cases, since they were not acute accidents, would have required a letter of recommendation from a hospital

\footnotetext{
${ }^{50}$ Marland, op. cit. (note 49), 67-8.

${ }^{51}$ Levene et al., op. cit. (note 2), 22.

52 Ibid., 22.
} 
governor, indicating 'the value placed both on the treatment and on the child's good health by the subscriber as well as by the parents'. ${ }^{53}$

The inpatient results summarised in Table 3 reveal that 80.7 per cent of child patients were discharged as 'cured'. Hospital governors and sponsors knew that rapid patient turnover and the discharge of many 'cured' individuals were beneficial to the reputations of the voluntary hospitals. ${ }^{54}$ This liberality appears to play a role in the London Hospital records. Two boys, a labourer's son and a shoemaker's son, were admitted to the London Hospital with fractured skulls and were discharged at four and nine days respectively as 'cured'. This short period of time is insufficient for any substantial healing to have taken place and reminds the contemporary researcher that 'cured' might have more complex meanings than at first assumed. Williams and Sharma noted a similar conundrum in their study of children admitted to hospital with neurological conditions such as epilepsy; many were described as 'cured', despite the fact that their conditions are clinically defined as incurable. ${ }^{55}$ Similarly, in the present investigation, eighty per cent of children with neurological conditions were discharged as 'cured'.

The application of the term 'cured' probably also applied to those who were making excellent progress in their recovery. Thomas Stevenson, a boy 'seven or eight years of age' was thrown from a cart and suffered a fracture of the elbow ' $1 \frac{1}{2}$ inch above the condyles, \& extending downwards into the joint, so that the condyles might be drawn from one another' as well as two superficial wounds to the elbow. ${ }^{56}$ His arm was splinted and bandaged at St George's Hospital and he was discharged cured two weeks after his admittance once it was noted that 'the union appears [reasonably] firm' ${ }^{57}$ According to modern clinical studies, fractures take approximately six weeks for substantial healing to occur, thus Thomas was discharged without a fully healed and remodelled injury, but was on the route to recovery. ${ }^{58}$

Traumatic conditions were the most common reason for admittance to the London Hospital for all three years under investigation. This result aligns with the hospital's policy of accepting acute accident cases outside regular patient admittance days. Early modern medical writers identified broken bones, as well as dislocations, hernias and wounds, as conditions that were generally easier to treat in children than adults. ${ }^{59}$ Surgical conditions, such as broken bones, were more likely to be treated in a hospital than by dispensaries, which catered more to medical issues. ${ }^{60}$ Table 4 displays the traumatic condition diagnostic label divided into subcategories. Boys were more commonly admitted to the London as trauma patients than girls; on average seventy-seven per cent of trauma cases were male children. Prognosis appears to have been mostly positive for those admitted with fractures. Only one of the thirty-two fractures was recorded as fatal; William

53 Levene et al., op. cit. (note 2), 25.

${ }^{54}$ Risse, op. cit. (note 1), 230.

55 Williams and Sharma, op. cit. (note 2), 426.

${ }^{56}$ Royal College of Surgeons MS0470/3/1 30-36 Case Histories for the Years 1805, n.p.

57 Ibid., n.p.

${ }^{58}$ M. Patrice Eiff and Robert Hatch, 'General principles of fracture care', in M. Patrice Eiff (ed.), Fracture Management for Primary Care, 3rd edn (Philadelphia: W.B. Saunders, 2012), 5-35: 6.

${ }^{59}$ François Mauriceau, The Diseases of Women with Child, and in Child-Bed: With Fit Remedies for the Several Indispositions of New-Born Babes (London: R. Ware, 1710); Helkiah Crooke, Mikrokosmographia, a Description of the Body of Man (1615).

${ }^{60}$ Loudon, op. cit. (note 38), 225; Croxson, op. cit. (note 43), 140; Alun Withey, 'Medicine and Charity in Eighteenth-Century Northumberland: The Early Years of the Bamburgh Castle Dispensary and Sugery, c.1772-1802', Social History of Medicine, 29 (2016), 467-89: 485. 


\begin{tabular}{lrrc} 
& \multicolumn{2}{c}{ Number of individuals } & \\
Body area fractured & $\mathrm{n}$ & $\%$ & Inpatient stay* \\
Skull & 3 & 9.4 & 22.7 \\
Scapula & 1 & 3.1 & 23.0 \\
Arm & 4 & 12.5 & 18.8 \\
Ribs & 1 & 3.1 & 55.0 \\
Thigh & 19 & 59.4 & 38.9 \\
Leg & 4 & 12.5 & 42.5 \\
N & 32 & &
\end{tabular}

* Inpatient stay is the average number of days spent in hospital by those children who were eventually discharged as 'cured' or 'relieved' (recorded as $\mathrm{n}$ ). The individual who died was not included in the average.

Table 5: Body areas fractured.

Bettes, age thirteen, was admitted on 22 November 1792 for a compound fracture of the leg and died on 27 January 1793.

Table 5 displays the anatomical areas fractured by children at the London Hospital. Children admitted with fractures who were discharged as 'cured' stayed in hospital for between four and sixty days; the average inpatient stay was thirty-five days. As mentioned above, two cases of skull fracture were discharged too early for substantial healing to take place. It is possible that some children were admitted with dramatic looking wounds that revealed themselves to be lacerations or severe sprains rather than fractures once they were cleaned. The length of stay for arm fractures is less than for those of the thigh and lower leg; it was in the hospital's best interest to discharge patients as soon as they were able and fractures that did not affect an individual's ability to walk clearly required less time as an inpatient. The childhood fracture most frequently treated at the London Hospital was the thigh or femoral fracture, a common childhood injury in modern clinical studies. ${ }^{61}$ These fractures are most commonly caused by accidents such as falls, sports, and collisions with vehicles. An individual presenting with a fractured thigh would most commonly be splinted: so that

'the limb may be kept permanently extended by splints being applied to it, while the trunk is attached to the head of the bedstead, \& the foot to the opposite end, by means of proper bandages... permanent extension may be effected without considerable difficulty. ${ }^{62}$

The average inpatient stay for thigh fractures, 38.9 days, is approximately sufficient time for the injury to heal in a clinical sense; femoral fractures take at least six weeks for significant healing to occur. ${ }^{63}$ The immobilisation and bed rest would allow sufficient healing to have occurred to allow the child to regain some mobility.

\section{Broken Bodies: Accidents, Injuries and Risks}

Simple fractures appear to have been treated as quotidian challenges by eighteenth-century surgeons; they were generally reduced, bound and splinted, and allowed time to heal. Compound injuries, in which the fractured bone pierces the skin and communicates with

\footnotetext{
61 James B. Hunter, 'Femoral Shaft Fractures in Children', Injury, 36 (2005), SA86-SA93, SA86.

62 RCS MS0470 38 Surgical Cases and Commentaries (1805-1807), Benjamin Brodie M.S. Surgical Cases and Commentaries, Vol. 1, n.p.

${ }^{63}$ Kimberly P. Stone and Klane White, 'Femoral Shaft Fractures in children' UpToDate, March 22, 2017, accessed August 2, 2017, http://www.uptodate.com/contents/femoral-shaft-fractures-in-children.
} 
the air, were greatly feared due to the risk of infection; however, the injuries were not universally fatal. In previous research, it was found that of the adult individuals admitted to the London and Middlesex hospitals for compound fractures, only 28.6 per cent of males and 35.3 per cent of females died as inpatients, suggesting that the majority of individuals who suffered compound fractures were not dying in hospital, though their prognosis following discharge is unknown. ${ }^{64}$

Two compound fractures experienced by children and recorded in contemporary physicians' notes resulted in dramatically different outcomes. Henry Davis, age nine, was struck by a falling chimney brick. Two hours after the accident he was brought to St George's by his mother. During the journey,

'he conversed cheerfully and rationally with her ... On his admission there was a wound on the right parietal bone $2 \frac{1}{2}$ inches in length, and on inserting the finger into it a deep depression of bone was felt, and small portions of Cerebrum were found mixed with coagulated blood. He is perfectly sensible and told the Nurse cheerfully that his head did not acke [sic]. ${ }^{65}$

Two months later Henry is to be discharged as an outpatient, but it is noted that

'there is, however, a large piece of bone to exfoliate. This morning a piece of brick came away from the wound about the size of the top of my little finger which no doubt had been lodged since the injury between the fractured portions of the cranium'. ${ }^{66}$

This example provides a window into the child's personality and also reveals a case in which an extreme injury was survived. The hospital records do not, of course, provide information on long-term health outcomes.

Edward [Quinton], a fifteen-year-old male who was admitted to St George's after falling from the top of a tree, was eventually a fatal case. His injuries were clearly severe, as:

'On his admission into the Hospital, a crepitus was discovered in some of the cervical vertebrae; the right clavicle, and one or two ribs were also fractured. The femur was broken about 3 inches about the knee, the bone had penetrated the skin making a large wound, and had also passed through the boy's trousers. He lay for some hours motionless, excepting his head which he occasionally moved. His extremities were cold, and pulse scarcely perceptible; and he occasionally uttered long. . cries expressive of the most horrible pain. It was a long time before the heat of the body returned, even with the assistance of bottles filled with hot water \&c-. ${ }^{67}$

These examples are important, not only because they exemplify opposite medical outcomes; they provide a view into the qualitative patient experiences of poor children, which were rarely recorded. ${ }^{68}$

Most fractures occur due to accidental traumatic injury. Seeking to access and reconstruct the context of historical fractures requires examination of the proximate (mechanical) and ultimate (cultural) causes of fractures. Clearly, without specific contextual evidence the cause of a fracture is simply speculative, but modern clinical data provide a framework in which to consider historical evidence. According to clinical data for the United States, vehicular trauma is the leading mechanism of injury, with falls as the second most common cause of injury. ${ }^{69}$ Falls onto an outstretched hand, for

\footnotetext{
${ }^{64}$ Mant, op. cit. (note 42), 331.

65 Royal College of Surgeons (RCS) MS0470/3/1 62 Surgical Cases and Commentaries, 1820-60, 55-7.

66 Ibid., 55-7.

${ }^{67}$ Ibid., 40-2.

${ }^{68}$ Hannah Newton, The Sick Child in Early Modern England, 1580-1720 (Oxford: Oxford University Press, 2012), 173 .

${ }^{69}$ Kenneth J. Koval and Michael Cooley, 'Experience in the United States', in R.W. Bucholz, J.D. Heckman, and C. Court-Brown (eds), Rockwood and Green's Fractures in Adults, 6th edn (Philadelphia, PA: Lippincott Williams \& Wilkins, 2006), 113-43: 122-4.
} 
example, may be the clear mechanism of injury, but the falls themselves may be caused by accidents or intentional pushes. ${ }^{70}$ Many factors influencing the risk of fracture due to falls have been investigated in the clinical literature, including age, health status, prescription medications, footwear, time of day, handedness, location and the type of fall. ${ }^{71}$ Studies specifically focused on children have identified playing, sports and vehicles as major contributing risk factors to children's fractures. ${ }^{72}$ These risks - particularly childhood play and the presence of vehicles - transcend time.

Eighteenth-century London was fraught with hazards. The health of a child born in eighteenth-century London was under pressure from birth, due to beliefs surrounding infant feeding and weaning. Newborns were often prevented from drinking nutrient-rich colostrum, the first milk produced by a new mother; the substance was deemed dangerous, probably due to its differing consistency and colour from later breast milk. ${ }^{73}$ In addition, in Britain the median age at weaning dropped from 18 months in the early sixteenth century to 7.25 months by the end of the eighteenth century, in part due to an increase in artificial feeding. ${ }^{74}$ Early weaning and the lack of colostrum robbed infants of the maternal antibodies in breast milk that aid in the support of the infant's immune system. ${ }^{75}$ Further, artificial feeding introduced nutritional challenges for infants which could lead to vitamin deficiencies such as scurvy, as weaning foods such as pap were generally of low quality, consisting of breadcrumbs or flour in milk or water. ${ }^{76}$ Rickets, caused by a lack of vitamin D, was present in children in rapidly industrialising English cities such as London and Birmingham due to inadequate access to sunlight. ${ }^{77}$ Urban overcrowding, pollution, inadequate sewage disposal and poor public hygiene led to epidemic outbreaks of diseases

${ }^{70}$ Osarumwense D. Osifo, Pius Iribhogbe and Hestia Idiodi-Thomas, 'Falls from Heights: Epidemiology and Pattern of Injury at the Accident and Emergency Centre of the University of Benin Teaching Hospital', Injury, 41 (2010), 544-7: 544.

${ }^{71}$ Sarah D. Berry and Ram R. Miller, 'Falls: Epidemiology, Pathophysiology, and Relationship to Fracture', Current Osteoporosis Reports, 6 (2008), 149-54; Cyrus Cooper et al., 'Incidence of Vertebral Fractures: A Population-Based Study in Rochester, Minnesota, 1985-1989', Journal of Bone and Mineral Research, 7 (1992), 221-7; Francesc Formiga et al., 'Characteristics of Falls Producing Hip Fractures in Nonagenarians', Journal of Nutrition, Health and Aging, 12 (2008), 664-7; Theresa H.M. Keegan et al., 'Characteristics of Fallers who Fracture at the Foot, Distal Forearm, Proximal Humerus, Pelvis, and Shaft of the Tibia/Fibula Compared with Fallers who do not Fracture', American Journal of Epidemiology, 159 (2004), 192-203; Naoakira Niino, Rumi Kozakai, and Maki Eto, 'Epidemiology of Falls among Community-Dwelling Elderly People', Nippon Ronen Igakkai Zasshi/Japanese Journal of Geriatrics, 40 (2003), 484-6; Crystal Luetters et al., 'Left-Handedness as a Risk Factor for Fractures', Osteoporosis International, 14 (2003), 918-22; Wenjun Li et al., 'Outdoor Falls among Middle-Aged and Older Adults: A Neglected Public Health Problem', American Journal of Public Health, 96 (2006), 1192-8; Mika Palvanen et al., 'The Injury Mechanisms of Osteoporotic Upper Extremity Fractures among Older Adults: A Controlled Study of 287 Consecutive Patients and their 108 Controls', Osteoporosis International, 11 (2000), 822-31.

72 Lennart Landin, 'Fracture Patterns in Children', Acta Orthopaedica Scandinavica, 54, Supplement 202 (1983), 3-109; Lennart Landin, 'Epidemiology of Children's Fractures', Journal of Pediatric Orthopaedics, 6 (1997), 79-83; Randall T. Loder, Patrick W. O’Donnell and Judy R. Feinberg, 'Epidemiology and Mechanisms of Femur Fractures in Children', Journal of Pediatric Orthopaedics, 26 (2006), 561-6.

73 Valerie A. Fildes, Breasts, Bottles and Babies: A History of Infant Feeding (Edinburgh: Edinburgh University Press, 1986), 81.

74 Ibid., 370

${ }^{75}$ M. Anne Katzenberg, D. Ann Herring and Shelley R. Saunders, 'Weaning and Infant Mortality: Evaluating the Skeletal Evidence', Yearbook of Physical Anthropology, 39 (1996), 177-99: 178.

${ }^{76}$ Fildes, op. cit. (note 73), 213.

${ }^{77}$ Simon Mays, Megan Brickley, and Rachel Ives, 'Skeletal Manifestations of Rickets in Infants and Young Children in a Historic Population from England', American Journal of Physical Anthropology 129 (2006), 36274; Theya Molleson and Margaret Cox with A.H. Waldron and D.K. Whittaker, The Spitalfields Project, 2: The Anthropology, The Middling Sort, CBA Research Report, 86 (Council for British Archaeology, 1993), 153. 


\begin{tabular}{|c|c|c|c|c|c|c|c|c|c|c|c|c|}
\hline \multirow[b]{2}{*}{ Year } & \multicolumn{12}{|c|}{ Month of the year } \\
\hline & Jan & Feb & Mar & Apr & May & Jun & Jul & Aug & Sep & Oct & Nov & Dec \\
\hline \multirow[t]{2}{*}{1760} & 7 & 4 & 3 & 6 & 7 & 9 & 8 & 4 & 9 & 7 & 5 & 6 \\
\hline & $(2)^{*}$ & (2) & (1) & (2) & (2) & (3) & (2) & (2) & (4) & (4) & (1) & (3) \\
\hline \multirow[t]{2}{*}{1791} & 2 & 10 & 3 & 2 & 3 & 1 & 2 & 3 & 3 & 5 & 2 & 4 \\
\hline & (0) & (5) & (1) & (1) & (2) & (1) & $(0)$ & (2) & (2) & (3) & (2) & (2) \\
\hline \multirow[t]{2}{*}{1792} & 2 & 3 & 3 & 4 & 7 & 6 & 4 & 2 & 5 & 3 & 5 & 2 \\
\hline & (1) & (2) & (1) & (2) & (4) & (2) & (2) & (2) & (1) & $(0)$ & (4) & $(0)$ \\
\hline \multirow[t]{2}{*}{ Average } & 3.7 & 5.7 & 3 & 4 & 5.7 & 5.3 & 4.7 & 3 & 5.7 & 5 & 4 & 4 \\
\hline & (1) & (3) & (1) & (1.7) & (2.7) & (2) & (1.3) & (2) & $(2.3)$ & (2.3) & (2.3) & (1.7) \\
\hline
\end{tabular}
for traumatic conditions in parentheses.

Table 6: Total number of child inpatients admitted per month ling number of inpatients with traumatic conditions.

such as dysentery, typhoid, diphtheria and typhus. ${ }^{78}$ Tuberculosis was common, spread by respiratory vectors and infected milk. ${ }^{79}$ Contemporary physicians recognised that these epidemic diseases tended to spread in the overcrowded 'narrow courts and alleys' of the city, reflecting an awareness of the socially differentiated levels of risk present across London. ${ }^{80}$

The London Hospital registers allow for a basic investigation of seasonality and its relationship to hospital admissions. Table 6 displays the number of child inpatients admitted by month and the number of child patients admitted into the most populous category, traumatic conditions. These data are represented graphically in Figure 1, in which the average number of child admissions per month and the average number of child admittances in the traumatic conditions category are displayed. There are three clear peaks in admittance: February, May-June, and September-October. The datasets chart a similar pattern, with the traumatic admissions clearly driving the admission peaks of February and May. These patterns may be artefacts of the small sample size, but there is value in comparing the data to studies of the relationship between accidental deaths recorded in the Bills of Mortality and seasonality. The winter months (November to February) were found to have higher than average incidence of burns and an increased number of scalds, posited to be related to the increased use of fires and preparation of hot foods indoors. ${ }^{81}$ In February there were two admissions for scalds and four for burns; two other burns were admitted in November. The Bills of Mortality reveal that the summer months and beginning of fall (May-October) yielded the highest number of fatal falls, construction accidents, deaths due to animals, and vehicle-related accidents. ${ }^{82}$ May, August, and October demonstrated the highest number of admissions for fractures and

\footnotetext{
${ }^{78}$ Roy Porter, 'Cleaning Up the Great Wen: Public Health in Eighteenth-Century London', Medical History, Supplement No. 11 (1991), 61-75: 63. Health risks in London are discussed broadly in Roy Porter, London: A Social History (London: Penguin, 2000); Anthony S. Wohl, Endangered Lives: Public Health in Victorian Britain (London: Methuen, 1983).

${ }^{79}$ Margaret Cox, Life and Death in Spitalfields 1700-1850 (York: Council for British Archaeology, 1996), 55.

80 John Coakley Lettsom, quoted in Charles Creighton, A History of Epidemics in Britain, Vol. 2 (Cambridge: Cambridge University Press, 1891-4), 133-4.

${ }^{81}$ Craig Spence, Accidents and Violent Death in Early Modern London 1650-1750, Studies in Early Modern Cultural, Political and Social History, Vol. 25 (Woodbridge: Boydell, 2016), 152.

${ }^{82}$ Ibid., 156.
} 


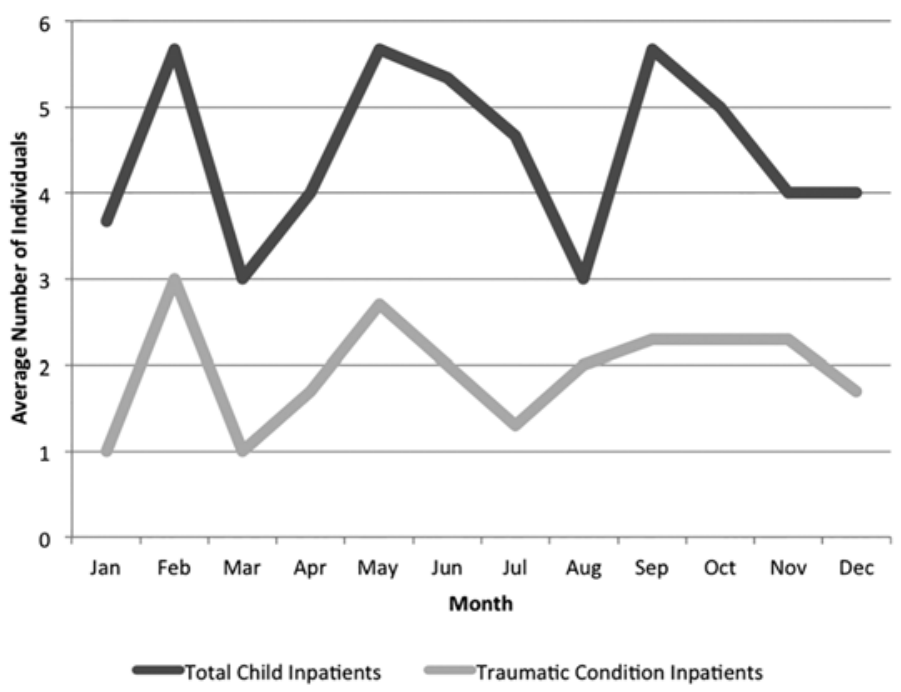

Figure 1: Average number of child admissions for traumatic conditions per month, compared with average total number of child admissions per month.

wounded body parts at the London Hospital, potentially reflecting the effects of children spending more time outdoors in the milder weather, thereby putting themselves at an increased risk for accidental injuries.

Using the London Bills of Mortality, Spence investigated the accidents and violent deaths that befell citizens of early modern London. ${ }^{83}$ Though drowning was the most commonly recorded reason for accidental death between 1654 and 1735, falls were in second place, forming 11.8 per cent of the total recorded cases. ${ }^{84}$ Vehicular accidents and being struck by various objects make up 5.4 per cent and 5.8 per cent of the total, respectively. Though children are not the primary focus of the work, Spence notes that children's 'limited abilities in judging distance and speed' increased their risk of suffering accidental trauma involving carts and horses. ${ }^{85}$ Many cases of accidents resulting in fractures probably never made it to the hospital; for example, John Cowley accidentally ran over three-year-old Edith Isham's head with his coach and was eventually charged with manslaughter. ${ }^{86}$ Many children were reported to have died due to accidental defenestration. For example, a two-and-a-half-year-old girl was admitted to St George's hospital, having fallen fourteen feet out of a window. It was noted upon her admittance that 'a considerable effusion of blood was found over the right parietal bone. Owing to this effusion it could not be ascertained whether there was any depression of bone or not' ${ }^{87}$ It was only upon dissection after her death that the diagnosis of fracture could be confirmed.

Other reasons for urban children's injuries are equally likely to befall children living in more rural areas. Burns were often recorded in the Bills of Mortality due to the use of

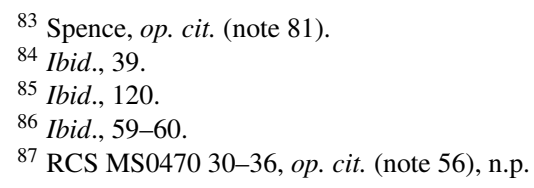


fire for cooking, lighting and heating. ${ }^{88}$ Children with epilepsy were apparently at risk of falling into fires; billowing clothing catching fire is cited on several occasions in the death records from St Bartholomew's Hospital as the reason for a child's death. ${ }^{89}$ The Bills of Mortality record fifty cases of children drowning; these were often domestic accidents involving water drawn for cooking or laundry or cases of children wandering too close to bodies of water. ${ }^{90}$ A previous study of historic childhood injury notes that children were often injured whilst enjoying leisure activities, such as 'playing ball or tag, running races, [and] attempting to be dare devils', demonstrating the difficulty in narrowing down specific proximate causes for the injuries detailed in the London Hospital records. ${ }^{91}$

Work undertaken by children may have put individuals at risk of injury. From an early age children were expected to take on tasks to assist their families. The range of activities depended upon the environment and age of the child; children in rural settings would probably have undertaken more varied tasks than those in cities and towns. ${ }^{92}$ It was, however, common for children to be involved in household and agrarian tasks such as cleaning, collecting water, herding livestock, tending gardens and fields, preparing meals and minding siblings. ${ }^{93}$ Some children in the London Hospital admission records have an occupation listed. Most of these are children in the eleven-to-thirteenage range, when work outside the home would have been the increasing focus of their lives. ${ }^{94}$ Apprenticeships, as noted above, generally started about age thirteen; those beginning apprenticeships were immediately put at greater risk of suffering accidents, catching epidemic diseases (for example, typhus, smallpox, tuberculosis), or ending up with occupational diseases. ${ }^{95}$ The occupational health and accidents of young workers, as recorded in coroners' records, has been investigated, though the focus is on the late medieval period. ${ }^{96}$ In the present investigation, six female seamstresses (ages eleven to thirteen) were admitted with complaints ranging from fevers to an inflamed foot to two neurological cases (paralysis and St Vitus's Dance). John Jenkins, a twelve-year-old errand boy from Whitechapel was admitted with a carious thumb, while a collection of servants and young labourers arrived at the London Hospital with various wounds, abscesses and contusions. Two fractured thigh cases, John French of Shoreditch and Richard Jones of Stepney, were listed as servants, but without further details it cannot be assumed their occupation was necessarily connected with their injury.

The proportion of admissions due to traumatic conditions is higher at the London Hospital than in any of the provincial cohorts studied by Levene and colleagues, particularly Chester and Manchester. ${ }^{97}$ Though in four of the six cohorts examined by

88 Ibid., 68-9.

${ }^{89}$ St Bartholomew's Archives and Museum, MR 5/5.

90 Spence, op. cit. (note 81), 90-1.

91 Barbara A. Hanawalt, The Ties That Bound: Peasant Families in Medieval England (New York: Oxford University Press, 1983), 271-3.

92 Patricia Crawford, Parents of Poor Children in England 1580-1800 (Oxford: Oxford University Press, 2010), 170.

93 Joanna M. Ferraro, 'Childhood in medieval and early modern times', in P.S. Fass (ed.), The Routledge History of Childhood in the Western World (London and New York: Routledge, 2013), 61-77: 65; Colin Heywood, 'Children's work in countryside and city', in P.S. Fass (ed.), The Routledge History of Childhood in the Western World (London and New York: Routledge, 2013), 125-41: 127.

${ }^{94}$ Heywood, op. cit. (note 93), 129.

95 Pelling, op. cit. (note 44), 156, 161.

96 Barbara A. Hanawalt, 'Childrearing among the Lower Classes of Late Medieval London', Journal of Interdisciplinary History, 8 (1977), 1-22; Hanawalt, op. cit. (note 91).

${ }^{97}$ Levene et al., op. cit. (note 2), 22. 
Levene and colleagues traumatic conditions were the most common reason for admission, the higher proportions evident in the London results is striking. The authors caution that 'local industry, epidemiology or environment clearly cannot give us the whole story'. ${ }^{98}$ These disparate results may suggest that London itself is a special case, and certainly the bustling urban environment of the metropolis posed higher risks of traumatic injury (particularly vehicular collisions and failures of infrastructure) for children than the provinces, though further records will need to be located and investigated to shed further light upon this characterisation. Certainly London 'afforded the best possible response to traumatic injury with regard to the availability of medical personnel' ${ }^{99}$ It is possible that in smaller settlements, with less robust medical infrastructure, more children were being treated for traumatic injuries at home, by itinerant medical providers, or by provincial surgeons whose records may have not survived or have yet to be discovered. Probing further into the character of the London Hospital, however, proves fruitful since the 'experience of hospitals was different' across London. ${ }^{100}$ The London Hospital was located 'in the centre of one of the densest and poorest districts, and in close proximity to the Docks', and was known in particular for its accident intake. ${ }^{101}$ In fact, the hospital itself recorded that 'the admission which is at all times freely given by night and by day to cases of accident and extreme urgency is one of the most important benefits conferred by the London Hospital'. ${ }^{102}$ This echoes the finding that the Manchester Infirmary admitted many children with 'sore eyes' complaints, suggesting a known specialty of the hospital. ${ }^{103}$

\section{Conclusion}

Examining the history of children in hospitals allows a more nuanced view into the broader history of accessing medical relief. A working poor family with a sick or injured child was tasked with navigating the medical marketplace to determine the best course of action. Despite a lack of specialised care for children in the eighteenth century and hospital rules dictating against accepting such patients, children were treated in eighteenth-century voluntary hospitals, including the London Hospital, for a variety of ailments. Children were admitted for reasons in direct violation of the hospital's admittance procedures, demonstrating that case-by-case evaluation sometimes resulted in lenient and solicitous decisions. Indeed, children were viewed as a future source of labour - natural resource thus treatment of conditions deemed curable was a worthwhile investment.

Overall, a lower proportion of children were admitted to the London Hospital than the provincial hospitals, but the proportion of traumatic cases accepted at the London is higher than any of the provincial cohorts studied by Levene and colleagues. This key finding potentially reflects the greater hazards to children present in the capital, where crowding and vehicular accidents were more likely to occur, but equally supports the London Hospital's contemporary reputation as an accident centre. Traumatic conditions were the most common reason for admission to the London Hospital and the in-hospital mortality rates for these conditions were low.

\footnotetext{
${ }^{98}$ Levene et al., op. cit. (note 2), 22.

${ }^{99}$ Spence, op. cit. (note 81), 168.

100 Woodward, op. cit. (note 15), 130.

101 Quoted in Ibid., 130.

102 Royal London Hospital Archives and Museum LH/A/5/18 Minute book of the house committee commencing 7 December 1824 (1830), 309.

${ }^{103}$ Levene et al., op. cit. (note 2), 26.
} 
The vast majority of child patients were discharged from the hospital as 'cured'. Despite the seemingly liberal use of the term, most children admitted with fractures appear to have spent enough time as inpatients for substantial healing to have occurred. Exceptions do exist; however, it is likely that children who were clearly on the mend were candidates for early discharge in order to free up beds for patients with acute concerns. It is difficult to locate information on post-discharge patient prognosis, but contemporary clinical writings indicate that both closed and compound fractures were common sights to eighteenthcentury medical practitioners and were often treated successfully.

The results of this study provide an intriguing view into the morbidity of children during the long eighteenth century. Further quantitative studies will provide a more detailed context in which to understand the risks to children's health in London. The major limitations to such investigations are the inconsistent recording practices employed in the voluntary general hospitals across England, most of which did not include patient age, and the limited survival of extant patient admission records. It is hoped that further records will be unearthed and examined to further amplify the voices of the historical child inpatient. In the meantime, existing studies of children's inpatient experiences will serve as critical historical context for bioarchaeological and palaeopathological studies of the skeletons of infants and children, a rapidly developing area of study. ${ }^{104}$ Bioarchaeological studies provide invaluable insight into the lives of individuals in the past. The marks left on bones by fractures, as well as chronic infectious and metabolic diseases, provide a tangible record of lived disease and injury experience that can be further contextualised by historical evidence such as that gleaned from hospital records.

Like their modern counterparts, children in the past fell ill and suffered accidents. Clearly parents could not always keep a watchful eye on their children, but a popular eighteenth-century nursery rhyme, adapted from a seventeenth-century ballad, contains the following admonishment:

\footnotetext{
'You parents all that children have

And you that have got none

If you would have them safe abroad

Pray keep them safe at home.' 105
}

The frequency of children being admitted for traumatic injuries suggests that they were a common occurrence, potentially an expected part of childhood. Working poor parents whose children did not readily stay 'safe at home' faced a complex nexus of choices regarding health care. It is to the modern observer's benefit that some chose to seek care at the voluntary general hospitals, leaving their marks and allowing a glimpse of the risks facing London's youngest residents.

\footnotetext{
104 Sian Halcrow and Nancy Tayles, 'The bioarchaeological investigation of children and childhood', in S.C. Agarwal and B.A. Glencross (eds), Social Bioarchaeology (Chichester: Wiley-Blackwell, 2011), 333-60; Mary Lewis, Paleopathology of Children: Identification of Pathological Conditions in the Human Skeletal Remains of Non-Adults (San Diego, CA: Elsevier, 2017).

105 I. Opie and P. Opie (eds), The Oxford Dictionary of Nursery Rhymes (Oxford: Oxford University Press, 1952), 118, no. 99 and plate V; adapted from The Lamentation of a Bad Market, or the Drownding of Three Children on the Thames (c.1680).
} 